\title{
ANALISA PEMILIHAN SAHAM UNTUK PORTOFOLIO OPTIMAL DENGAN METODE KRITERIA SEDERHANA
}

\author{
Mohammad Lukman ${ }^{1}$, Moch. Hari ${ }^{2}$
}

\begin{abstract}
Generally, problem faced in making a portfolio is the large number of probabilities in risky active stock combinations available at stock market. Yet, if we put riskless active stock into those combinations. Considering this numerous possibilities of portfolio made from stocks at stock market, a question that will arise is which portfolio to be chosen by investors. If acting rationally, the investors will chose an optimum portfolio.

Simple criteria method is an alternative method in forming the optimum portfolio with objective in determining stock rank in efficient limit. This method was firstly developed by Elton Edwin, Gruber, and Padberg (1976) and exposed in Journal of Finance. The calculation made refers to Single-Index Model, a model result from simplification of Markowitz model, such that the calculation will be easier and more practical. Based on examination, it is identified that return correlation among securities (particularly on stock) occurs because of response to changes in general market index.

Research conducted at BES ( Surabaya Stock Market), within period of December 1999 to August 2001, using monthly data had shown that by using method of "Simple criteria for optimal portfolio selection" it is known from 173 stock, that stocks included in optimum portfolio only 12 (or 6,94\%) stock are: Makindo, Mas Murni Indonesia, Sarasa Nugraha, Jakarta Int I Hotel \& Dev., sari Husada, Ultra Jaya Milk, Prasdha aneka, Ever Shine Textile Ind., Tirta Mahakam Plywood, Asahimas Flat Glass, semen Gresik, dan Unilever Indonesia with proportion of $72.08 \%$; $4.24 \% ; 12.28 \% ; 1 \% ; 0.63 \% ; 0.5 \% ; 0.44 \% ; 0.18 \%$; and $0.45 \%$ respectively.
\end{abstract}

\section{Key Words : Stock, Portfolio, Simple Criteria Method.}

\section{PENDAHULUAN}

Saham merupakan instrumen yang paling umum yang diperdagangkan dalam pasar modal (bursa efek). Saham dapat didefinisikan sebagai, surat bukti penyertaan dalam kepemilikan Perseroan Terbatas atau disebut juga dengan emitten. Keuntungan yang diperoleh bagi pemegang saham / Investor adalah pada deviden dan capital gain.

Fluktuasi kurs saham yang terjadi di pasar modal menyebabkan timbulnya ketidakpastian atas besarnya capital gain/loss yang diperoleh para investor. Bagi investor, disamping mendatangkan keuntungan juga dapat mengandung resiko investasi di pasar modal. Kelaziman yang sering dijumpai adalah bahwa semakin besar return yang diharapkan (expected) maka akan semakin besar pula resiko yang dihadapi (Journal UNIGA - MM; Desember 2000).

Starategi yang sering digunakan dalam kondisi investasi yang beresiko adalah membentuk portofolio. Hakekat dari pembentukan portofolio adalah mengalokasikan dananya pada berbagai alternatif investasi, sehingga resiko investasi secara keseluruhan dapat diminimumkan. 
Resiko yang relevansi untuk dipertimbangkan adalah Systematic risk, karena resiko tersebut berpengaruh terhadap kondisi pasar secara keseluruhan dan tetap ada meskipun telah dilakukan diversifikasi dengan baik.

\section{TINJAUAN PUSTAKA}

Model yang dikembangkan oleh Elton, dkk (1976). Dengan menyatakan "Simple Criteria For Optimal Portofolio Selection" merupakan metode alternatif dalam pembentukan portofolio optimal yang bertujuan untuk menentukan peringkat saham dalam batas yang efisien, dengan mendasarkan pada rasio Excess Return To Beta (ERB), sebuah parameter yang digunakan untuk mengevaluasi kinerja portofolio. Sedangkan perhitungan yang digunakan untuk menganalisa investasi pada sekuritas adalah mengacu pada "Single Index Model".

Model indeks tunggal berusaha menyederhanakan analisis portofolio, yaitu yang berkaitan dengan jumlah dan jenis input (data), serta prosedur analisis untuk menentukan portofolio yang optimal (Sri Handaru Yuliati, p.49, 1996). Hal ini dapat dilakukan karena dalam Single Index Model diasumsikan bahwa korelasi return antar sekuritas terjadi karena bereaksi terhadap perubahan pada general market index.

Terdapat dua hal yang perlu diperhatikan dalam penelitian ini yaitu, tingkat keuntungan (return) yang diperoleh dan tingkat resiko yang dihadapi. Oleh karena itu dalam penyusunan skripsi ini akan dipaparkan mengenahi prosedur analisis untuk menentukan portofolio yang optimal dengan metode kriteria sederhana.

\section{Teori Portofolio}

Portofolio diartikan sebagai serangkaian kombinasi beberapa aktiva yang diinvestasi dan dipegang oleh investor, baik perorangan maupun lembaga. Kombinasi aktiva tersebut bisa berupa aktiva riil, aktiva finansial ataupun keduanya. Seorang investor yang menginvestasikan dananya di pasar modal biasanya tidak hanya memilih satu saham saja. Alasanya, dengan melakukan kombinasi saham investor bisa meraih return yang optimal sekaligus akan memperkecil resiko melalui diversifikasi.

Dalam konteks portofolio pasar, harus di pahami adanya resiko investasi yang terdiri dari 2 (dua) komponen yaitu :

1. Resiko tidak sistematik (Unsystematic risk).

Di definisikan sebagai resiko yang terkait dengan suatu saham tertentu yang umumnya dapat di hindari (avoidable) atau di perkecil melalui di versifikasi.

2. Resiko sistematik (Systematik risk).

Didefinisikan sebagai resiko pasar yang bersifat umum dan berlaku bagi semua saham dalam pasar modal yang bersangkutan.

Sedangkan tujuan yang hendak di capai dalam pembentukan portofolio adalah sebagai berikut : 
- Pada tingkat resiko tertentu berusaha mencapai keuntungan yang maksimal

- Atau, pada tingkat keuntungan tertentu berusaha mencapai resiko yang minimal.

Langkah - Langkah Investasi Portofolio.

Dalam melakukan investasi portofolio perlu dilakukan langkah langkah sebagai berikut :

\section{Meningkatkan kebijakan investasi}

Pada langkah ini Manajer Investasi perlu mengenali tujuan investasi dari kliennya, terutama yang menyangkut sikapnya terhadap Trade - off antara resiko dan tingkat keuntungan yang diharapkan.

\section{Melakukan Analisis Sekuritas.}

Pada langkah ini dilakukan analisis untuk membandingkan antara market value dengan intrinsic value, dengan maksud untuk mengetahui apakah terjadisituasi mis priced.

\section{Membentuk Portofolio.}

Memilih sekuritas - sekuritas mana yang akan dibeli dan berapa banyak dana yang akan diinvestasikan pada sekuritas sekuritas tersebut.

\section{Merevisi Portofolio.}

Menentukan mana sekuritas dalamportofolio yang akan di ganti, dan sekuritas mana yang akan dibeli sebagai penggantinya.

\section{Menilai kinerja Portofolio.}

Apakah tingkat keuntungan yang diperoleh dari portofolio tersebut sesuai deangan resiko yang ditanggung? pembandingan perlu dilakukan dengan benchmark yang dipilih.

\section{Nilai yang diharapkan (Expected Return) \\ Expected return pada dasarnya, merupakan rata - rata tertimbang dari berbagai return historis, dengan} probabilitas masing - masing return sebagai faktor penimbangnya. Expected Return di cerminkan rata - rata (mean) dari distribusi probablilitas tingkat keuntungan. Untuk mengestimasikan Expected return sekuritas individual, perlu dihitung dulu harga perlembar saham (bila data deviden diabaikan). Maka, dapat diformulasikan :

$$
R_{i t}=\frac{\left\lfloor P_{i t}-P_{i}(t-1)\right\rfloor}{P_{i}(t-1)}
$$

Dan untuk expected Return diformulasikan sebagai berikut ;

$$
\begin{gathered}
E(R i)=\frac{\sum_{i=1}^{N} R_{i t}}{N} \\
\text { Dimana } E(R i) \text { adalah tingkat }
\end{gathered}
$$

keuntungan yang diharapkan dari investasi i.

\section{Karakteristik resiko investasi.}

Menurut Van Horne (1997,p.37), resiko merupakan kemungkinan penyimpangan tingkat keuntungan yang sesungguhnya dari tingkat keuntungan yang di harapkan (expected return). Resiko suatu investasi di ukur dari besarnya Varians atau Standar Deviasi dari Expected return. Semakin besar tingkat penyebaran maka investasi menjadi semakin beresiko. 
Resiko sekuritas dapat di hitung dengan rumus :

$$
\delta_{i}^{2}=\sum_{t=1}^{n} \frac{\left[\left(R_{i t}-E\left(R_{i}\right)\right)\right]^{2}}{n-1}
$$

Dimana $\delta_{i}^{2}$ adalah Varians saham i

dan $\delta_{i}$ adalah deviasi standart saham i

\section{Model Indeks Tunggal}

\section{Konsep Model Indeks Tunggal}

Kalau kita melakukan pengamatan maka akan nampak bahwa pada saat "pasar" membaik (yang juga ditunjukan oleh indeks pasar yang tersedia) harga saham - saham individual juga meningkat. Demikian pula sebaliknya pada saat pasar memburuk maka harga saham - saham akan turun harganya. Hal ini menunjukan bahwa tingkat keuntungan suatu saham nampaknya berkorelasi dengan perubahan pasar. Kalau perubahan pasar bisa dinyatakan sebagai tingkat keuntungan indeks pasar, maka tingkat keuntungan suatu saham bisa dinyatakan sebagai ;

$$
R_{i}=a_{i}+\beta_{i} R_{m}
$$

Berikut ini disajikan beberapa karakteristik dari model indeks tunggal (Elton dan Gruber, 1991, pp. $101-107)$.

Diantaranya adalah;

1.Persamaan dasar.

$$
\begin{aligned}
& R_{i}=a_{i}+\beta_{i} R_{m} \\
& a_{i}=\alpha_{i}+e_{i} \\
& R_{i}=\alpha_{i}+\beta_{i} R_{m}+e_{i}, i=1,2 . ., n
\end{aligned}
$$

\section{Berdasarkan Pembentukan persamaan}

$$
\text { Rata }- \text { rata } e_{i}=E\left(e_{i}\right)=0
$$

3. Berdasarkan asumsi
Indeks tidak berhubungan dengan unique return :

$\mathrm{E}\left[\mathrm{e}_{\mathrm{i}}\left(\mathrm{R}_{\mathrm{m}}-\mathrm{E}\left(\mathrm{R}_{\mathrm{m}}\right)\right)\right]=0$ ), untuk setiap saham $\mathrm{i}=1, . ., \mathrm{N}$

Sekuritas berkorelasi hanya karena memberikan respon terhadap pasar:

$E\left(e_{i} e_{j}\right)=0{ }^{i i)}$, untuk setiap pasangan saham $\mathrm{i}=1, \ldots, \mathrm{N}$ tetapi $\mathrm{i} \neq \mathrm{j}$

4. Berdasarkan definisi.

Varians $\mathrm{e}_{\mathrm{i}}=\mathrm{E}\left(\mathrm{e}_{\mathrm{i}}\right)^{2}=\delta_{e i}{ }^{2}$

Varians $R m=E\left(R_{m}-R_{m}{ }^{2}\right)=\delta_{m}{ }^{2}$

Berdasarkan karakteristik diatas, penggunaan model indeks tunggal :menghasilkan :

1. Tingkat keuntungan yang diharapkan

$$
E\left(R_{i}\right)=\alpha_{i}+\beta_{i} E\left(R_{m}\right)
$$

2. Variance tingkat keuntungan,

$$
\delta_{i}{ }^{2}=\beta_{i}^{2} \delta_{m}{ }^{2}+\delta_{e i}{ }^{2}
$$

3. Covariance tingkat keuntungan sekuritas i dan j,

$$
\delta_{i j}=\beta_{i} \beta_{j} \delta_{m}^{2}
$$

Perhatikan bahwa model tersebut menunjukan bahwa tingkat keuntungan yang diharapkan terdiri dari dua komponen; bagian unik, yaitu $\alpha_{\mathbf{l}}$ dan bagian yang berhubungan dengan pasar, yaitu $\beta \mathrm{l} E(\mathrm{Rm})$. Demikian juga variance tingkat keuntungan terdiri dari dua bagian unik $(\delta \varepsilon 12)$ dan resiko yang berhubungan dengan pasar $\beta \mathrm{t}^{2} \delta \mathrm{m}^{2}$. Sebaliknya covariance semata - mata tergantung pada resiko pasar. Ini berarti bahwa model indeks tunggal menunjukan bahwa satu - satunya alasan mengapa saham 
"bergerak bersama" adalah bereaksi terhadap gerakan pasar.

\section{Model Indeks Tunggal Untuk Portofolio.}

Model indeks tunggal akan mampu mengurangi jumlah variabel yang perlu ditaksir karena untuk portofolio model indeks tunggal mempunyai karakteristik sebagai berikut. Beta portofolio merupakan rata - rata tertimbang dari beta saham saham yang membentuk portofolio tersebut. Diformulasikan sebagai berikut ;

$$
\beta_{p}=\sum X_{i} \beta_{i}
$$

Demikian juga alpha portofolio, dirumuskan

$$
\alpha_{p}=\sum X_{i} \alpha_{i}
$$

Dengan demikian persamaan diatas dapat dituliskan sebagai berikut ;

$$
E\left(R_{p}\right)=\alpha_{p}+\beta_{p} E\left(R_{m}\right)
$$

Untuk Variance portofolio, rumusnya bisa dinyatakan sebagai berikut ;

$$
\delta_{p}{ }^{2}=\beta_{p}{ }^{2} \delta_{m}{ }^{2}+\sum X_{i}{ }^{2} \delta_{e i}{ }^{2}
$$

Apabila pemodal menginvestasikan dananya dengan proporsi yang sama pada $\mathrm{N}$ saham, maka variance portofolio bisa dinyatakan sebagai,

$\delta_{p}^{2}=\beta_{p}^{2} \delta_{m}{ }^{2}+(1 / N)\left[\sum(1 / N)\left(\delta_{e j}{ }^{2}\right)\right]$

Apabila nilai $\mathrm{N}$ menjadi makin besar (artinya makin banyak saham yang dipergunakan untuk membentuk portofolio), makin kecillah nilai term kedua dari persamaan tersebut. Karena term tersebut menunjukan resiko sisa (residual risk atau unsystematics risk) maka ini berarti bahwa sumbangan resiko portofolio menjadi makin kecil apabila kita memperbesar jumlah saham yang ada dalam portofolio. Apabila kita mempunyai $\mathrm{N}$ yang besar sekali, maka term tersebut akan mendekati sangat kecil dan mendekati nol. Sedangkan term yang pertama disebut sebagai unsystematics risk. Penjumlahan kedua term tersebut disebut sebagai resiko total dari portofolio $\left(\delta_{\mathrm{p}}{ }^{2}\right)$.

Resiko yang tidak bisa dihilangkan kalau kita membentuk portofolio yang terdiri dari sekuritas yang makin banyak, merupakan resiko yang berkaitan $\beta_{p}$. Kalau kita menganggap resiko residual mendekati nol, maka resiko portofolio mendekati

$$
\delta_{p}=\left[\beta_{p}{ }^{2} \delta_{m}^{2}\right]^{/ 2}=\beta_{p} \delta_{m}=\delta_{m}\left[\sum X_{i} \beta_{i}\right]
$$

Karena $\delta_{m}$ nilainya sama, tidak peduli saham apapun yang kita analisis, ukuran kontribusi resiko suatu saham terhadap resiko portofolio yang terdiri dari banyak saham akan tergantung pada $\beta_{i}$.

Resiko sekuritas individual adalah $\beta_{i}{ }^{3} \delta_{m}{ }^{2}+\delta_{e i}{ }^{2}$ karena pengaruh $\delta_{e i}{ }^{2}$ pada resiko portofolio bisa dikurangi kalau portofolio terdiri dari makin banyak saham, maka $\delta_{e i}{ }^{2} \quad$ sering juga disebut sebagai diversifiable risk tetapi pengaruh pada resiko portofolio tidaklah bisa dikurangi dengan menambah sekuritas dalam portofolio. Karena itu $\beta_{i}$ merupakan nondiversifiable risk. Karena diversifiable risk bias dihilangkan dengan memperbesar jumlah sekuritas dalam portofoli, $\beta_{i}$ sering dipakai sebagai pengukur resiko portofolio. 
Menaksir Nilai Beta

Beta menunjukan kemiringan (Slope) garis regresi tersebut, dan alpha menunjukan intercept dengan sumbu riil. Semakin besar beta, semakin curam kemiringan garis tersebut, dan sebaliknya penyebaran titik - titik pengamatan disekitar garis regresi tersebut menunjukan resiko sisa $\left(\delta_{\mathrm{ei}}{ }^{2}\right)$ sekuritas yang diamati. Semakin menyebar titik tersebut, semakin besar resiko sisanya.

Beta bisa dihitung dengan menggunakan formulasi :

$$
\beta_{i}=\left(\delta_{i m} / \delta_{m}{ }^{2}\right)
$$

dan, untuk alpha bisa dihitung dengan:

$$
\alpha_{i}=E\left(R_{i}\right)-\beta i E\left(R_{m}\right)
$$

Rasio $\left(\delta_{i m} / \delta_{m}{ }^{2}\right)$ adalah beta atau kepekaan pasar dari suatu saham. Saham dengan beta lebih besar dari 1,0 merupakan saham yang sangat peka terhadap perubahan pasar, dan sebaliknya. Saham dengan beta lebih besar dari 1disebut sebagai saham yang agresif, sedangkan yang mempunyai beta kurang dari 1 disebut sebagai saham yang defensif.

$$
\text { Apabila } \beta=1 \text {, maka kemiringan }
$$
garis tersebut adalah $45^{\circ}$ (kalu kita menggunakan skala yang sama). Semakin besar nilai beta, semakin curam kemiringan garis tersebut, begitu pula sebaliknya.

\section{Pemilihan Portofolio dengan Metode}

\section{Kriteria Sederhana.}

Elton Edwin, Gruber dan Padberg (1976), mengemukakan sebuah alternatif untuk memilih saham mana yang masuk ke dalam portofolio dengan menggunakan excess return to beta (ERB) dimana ERB merupakan selisih antara tingkat pengembalian saham dengan tingkat pengembalian aset bebas resiko yang selanjutnya dibagi dengan beta saham tersebut. Excess return to beta ini diurutkan dari yang terbesar sampai yang terkecil. ERB mengukur tambahan tingkat pengembalian pada sebuah saham perunit dari resiko yang tidak dapat didiversifikasi. ERB dihitung sebagai berikut; ${ }^{1)}$

$$
E R B=\frac{(E(R i)-R f)}{\beta_{i}}
$$

Dimana :

$\mathrm{ERB}=$ Excees Return To Beta.

$\mathrm{R}_{\mathrm{i}} \quad=$ Tingkat pengembalian saham $\mathrm{ke}-\mathrm{i}$

$\mathrm{R}_{\mathrm{f}} \quad$ Tingkat pengembalian asset bebas resiko

$\beta_{\mathrm{i}}=$ Beta saham $\mathrm{ke}-\mathrm{i}$

Selanjutnya Elton dkk, memberikan rumusan mengenahi saham - saham yang masuk dalam portofolio yaitu saham saham yang memiliki ERB diatas dari batas tertentu yang disebut dengan Cut - Off Rate di hitung sebagai berikut ;

$$
C_{i}=\delta_{i}^{2} \frac{\sum_{j=1}^{i} \frac{R_{i}-R_{f}}{\delta^{2}{ }_{e i}}}{1+\delta_{i}{ }^{2} \sum_{j=1}^{i} \frac{\beta_{i j}}{\delta^{2}}}
$$

Atau, dapat juga digunakan rumus, sebagai berikut ;

$$
C_{i}=\frac{\delta_{m}{ }^{2} \sum_{j=i}^{i} \frac{\left(R_{i}-R_{f}\right) \beta_{i j}}{\delta_{e j}{ }^{2}}}{1+\delta_{m}{ }^{2} \sum \frac{\beta_{i j}}{\delta_{e j}{ }^{2}}}
$$

$\mathrm{C}_{\mathrm{i}}=$ Cutt - off rate 


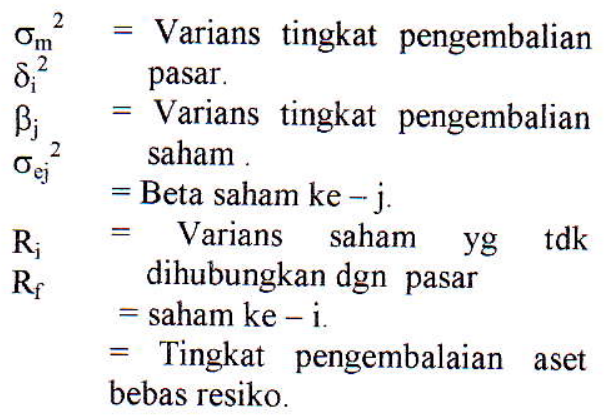

Dengan membandingkan nilai ERB

dan Ci. Maka, seleksi pembentukan portofolio dapat ditentukan sebagai berikut; Jika;

ERB $>C_{i}:$ Maka, saham yang bersangkutan termasuk dalam portofolio.

ERB $<\mathrm{C}_{\mathrm{I}}:$ Maka, saham yang bersangkutan tidak termasuk dalam portofolio.

Setelah nilai $C_{I}$ dihitung maka di tetapkan batas pemisah (Unique Cut - Off Point $=C^{*}$ ), $\mathrm{C}^{*}$ di pilih dari nilai ERB $>\mathrm{C}_{\mathrm{i}}$, yang paling bawah (portofolio yang paling rendah)

$$
C^{*}=\left\{\left(R_{i}-R_{f}\right) / \beta_{i}\right\}>C_{i}
$$

Nilai $\mathrm{Zi}$ dan $\mathrm{Xi}$ dapat dihitung, setelah nilai $\mathrm{C}^{*}$ ditentukan dengan formulasi ; 11)

$$
\begin{gathered}
Z_{i}=\frac{\beta_{i}}{\delta_{e i}}\left[\frac{\left(R_{i}-R_{f}\right)}{\beta_{i}}-C^{*}\right] \\
X i=Z i / \sum_{i=1}^{N} Z i
\end{gathered}
$$

Setelah semua perhitungan dilakukan, maka hasilnya akan berupa daftar saham - saham yang masuk seleksi (saham yang diterima kedalam portofolio) dengan proporsinya masing - masing.

\section{Penilaian Kinerja Portofolio.}

Langkah terakhir dalam proses investasi pada sekuritas adalah melakukan penilaian terhadap kinerja (performance) investasi tersebut. Karena investasi pada sekuritas sering dilakukan dalam bentuk portofolio, maka kita perlu melakukan evaluasi terhadap kinerja portofolio. Penilaian kinerja portofolio perlu dilakukan untuk mengetahui apakah pilihan investasi kita memang bisa memberikan hasil yang baik (sesuai dengan resikonya) ataukah tidak. Portofolio yang sering di nilai adalah portofolio yang dikelola oleh perusahaan perusahaan pengelola dana

Penilaian kinerja portofolio bisa dilakukan dengan perbandingan langsung, ataupun dengan menggunakan ukuran tertentu. Dalam penilaian tersebut kita perlu memperhatikan bukan hanya tingkat yang diperoleh,tetapi juga risiko portiofolio tersebut. Risiko bisa dinyatakan sebagai deviasi standart tingkat keuntungan, ataupun beta. Penggunaan ukuran tertentu dilakukan dengan menggunakan parameter parameter.

Diantara parameter tersebut adalah :

(1) Excess return to variability measure.

(2) Differential return dengan resiko sebagai deviasi standar.

(3). Excess return to beta.

(4) Differential return dengan diukur sebagai beta. Sedangkan dalam penelitian ini, parameter yang digunakan adalah Excess return to beta. 


\section{Excess Return To Beta,}

adalah Portofolio - portofolio yang digambarkan pada diagram dimana sumbu datarnya adalah beta dan sumbu tegaknya tingkat keuntungan yang diharapkan, akan membentuk garis lurus dengan Rf.

Kemiringan garis lurus antara portofolio A dengan $\mathrm{Rf}$ adalah [E(RA)-Rf]/BA. Sama seperti excess return to standart deviation, para pemodal akan lebih menyukai portofolio yang mempunyai kemiringan garis yang paling besar.

Gambar 2.3 portofolio yang paling disukai adalah portofolio A, kemudian diikuti B,C dan D. rasio antara excess return dengan deviasi standar, maka ukuran Treeynor ini akan dipilih yang tertinggi.

\section{METODOLOGI PENELITIAN}

Identifikasi masalah dimaksudkan untuk mempelajari lebih detail terhadap permasalahan yang akan dijadikan tema / obyek dari pelaksanaan penelitian. Sedangkan untuk menunjang kegiatan tersebut penulis mempelajari dari buku buku, majalah, journal atau bahan - bahan tertulis lainnya, baik berupa teori atau laporan terdahulu (findings). $\mathrm{Hal}$ ini dimaksudkan untuk mempermudah didalam membuat model pemecahannya.

Masalah yang akan dikaji dalam penelitian ini adalah tentang pembentukan portofolio, dengan mengacu pada teori "Simple Criteria For Optimal Portofolio Selection", dan data yang digunakan sebagai pengamatan adalah data saham biasa yang listing di BES priode $1999-2000$.

\section{Penetapan Tujuan.}

Tujuan penelitian merupakan langkah yang harus ditetapkan terlebih dahulu, setelah diperoleh kejelasan dari permasalahannya. Hal ini dimaksudkan agar hasil (output) yang akan dicapai menjadi lebih terarah dan selaras dengan tujuan semula

\section{Penentuan variabel penelitian}

Diantara variabel penelitian yang digunakan adalah :

6. Harga Pasar Satuan (i) adalah harga perlembar saham pada saham secara individual.

$\approx$ Keuntungan Saham Individual (Ri) adalah : Tingkat return yang diharapkan pada saham secara individual.

๙ Tingkat keuntungan bebas resiko (Rf). adalah tingkat pendapatan dari suatu investasi yang mempunyai proporsi tetap terhadap nilai investasinya

$\omega$ Keuntungan Portofolio (Rp).adalah Tingkat Return investasi yang diharapkan dari pembentukan portofolio.

$\omega$ Resiko Portofolio $\left(\delta_{p}\right)$ adalah kemungkinan bahwa hasil yang diharapkan dari investasi berbeda dengan hasil yang dicapai.

\section{a. Teknik Pengambilan Sampel.}

Dalam Penelitian ini digunakan data bulanan yang telah dilakukan perbaikan (adjusted) atas adanya data dividen, bonus, right issue 
yang telah dilakukan perusahaan. Priode penelitian adalah perusahaan yang terdaftar sejak tahun 1999 sampai 2001. perusahaan yang tidak memiliki perdagangan selama 3 kali berturut -turut akan dikeluarkan dari daftar sample penelitian. Hal ini dimaksudkan untuk memudahkan dalam perhitungan portofolio. Dari seleksi data yang dilakukan ternyata terdapat 173 data yang akan diteliti.

b. Sumber data.

Dalam penelitian ini menggunakan data skunder karena data diperoleh secara langsung di PT. Bursa Efek Surabaya. Data - data tersebut antara lain adalah ;

1 Data harga saham bulanan.

Data ini diambil dari data perusahaan yang listing di BES setiap akhir bulan, yang akan digunakan untuk menghitung keuntungan saham dan pasar. Data - data tersebut antara lain adalah :

$>$ Data harga saham bulanan untuk desember 1999

$>$ Data harga saham bulanan priode Januari - Desember 2000.

$>$ Data harga saham bulanan priode Januari - Agustus 2001

1. Data SBI.

Data ini diambil dari suku bunga SBI yang telah dikeluarkan oleh Bank Indonesia. Data yang digunakan adalah tahun 2001, yang dalam olahan statistik data ini harus dirubah menjadi data bulanan. Data ini nantinya akan digunakan sebagai pendekatan dalam menentukan tingkat bunga bebas resiko yang akan dipakai untuk menghitung portofolio saham yang optimal
Secara sistematis, langkah yang di lakukan dalam pemecahan masalah adalah sebagai berikut :

Tahap 1:

Menghitung Keuntungan

saham \& pasar

$$
R_{i t}=\frac{\left[P_{i t}-P_{i}(t-1)\right]}{P_{i}(t-1)}
$$

Menghitung Expected ReturnSaham \& pasar

$$
E(R i)=\sum_{j=1}^{m} \frac{R_{i t}}{N} .
$$

Tahap 2 :Menghitung Varians \& Standar Deviasi.

$$
\delta_{i}^{2}=\sum_{t=1}^{N} \frac{\left[\left(R_{i t}-E\left(R_{i}\right)\right)\right]^{2}}{n-1}
$$

Menghitung Standart deviasi saham

$$
\delta_{i}=\sqrt{\delta^{2}}
$$

Tahap 3 : Menentukan Koefisien Beta

$$
\text { (ß). } \beta_{i}=\frac{\delta_{i m}}{\delta_{i} \delta_{m}}
$$

Tahap 4: Menentukan Koefisien Alfa

$$
\alpha_{i}=E(R i)-\beta_{i} . E(R m)
$$

Tahap 5: Menghitung Unsystematic risk.

$$
\delta_{e i}{ }^{2}=\delta_{i}{ }^{2}-\beta_{i}{ }^{2} \delta_{m}{ }^{2}
$$

Tahap 6: Menentukan tingkat bunga bebas resiko

Diolah dari Suku Bunga Sertifikat Bank Indonesia (SBI).

Tahap 7:Penentuan Portofolio Optimal dengan Metode Kriteria Sederhana (Simple Criteria For Optimal Selection), adalah;

- Tentukan nilai dari Excess Return To Beta (ERB), yaitu : 


$$
E R B=\frac{(E(R i)-R f)}{\beta_{i}}
$$

( Data diurutkan mulai dari tingkat yang besar sampai pada tingkat yang kecil).

- Menentukan saham yang akan diikutkan ke dalam portofolio optimal.

$>$ Menghitung kandidat saham $\left(C_{i}\right)$.

$$
C_{i}=\delta_{i}^{2} \frac{\sum_{j=1}^{i} \frac{R_{i}-R_{f}}{\delta_{e i}^{2}}}{1+\delta_{i}{ }^{2} \sum_{j=1}^{i} \frac{\beta_{i}}{\delta_{e j}^{2}}}
$$

Setelah nilai $C_{i}$ dihitung maka di tetapkan batas pemisah (Unique Cut Off Point $=C^{*}$ ) Ketentuannya bahwa $C^{*}=\left\{\left(E\left(R_{i}\right)-R_{f}\right) / \beta_{i}\right\}>C_{i}$

(Data diambil yang paling bawah)

- Hitung nilai $\mathrm{Zi}$ berikut untuk menentukan ukuran proporsi untuk $\mathrm{k}$ sekuritas pertama :

$$
Z_{i}=\frac{\beta_{i}}{\delta_{e i}}\left[\frac{\left(E\left(R_{i}\right)-R_{f}\right)}{\beta_{i}}-C^{*}\right]
$$

- $\quad$ Bagi tiap $\mathrm{Zi}$ dengan jumlah $\mathrm{Zi}$ untuk mentranformasi mereka keproporsi $\mathrm{Xi}$ untuk setiap sekuritas :

$$
X_{i}=\frac{Z_{i}}{\sum_{j=i}^{n} Z_{j}}
$$

- Setelah semua perhitungan dilakukan maka hasilnya akan berupa daftar daftar saham - saham yang masuk seleksi (saham yang diterima) dengan proporsinya masing- masing saham tersebut.

Tahap 8; Menghitung Tingkat keuntungan Portofolio

$$
\mathrm{E}\left(\mathrm{R}_{\mathrm{p}}\right)=\alpha_{p}+\beta_{p} E\left(R_{m}\right)
$$

Standar deviasi portofolio dapat dihitung dengan rumus ;

$$
\delta_{p}^{2}=\beta_{p}^{2} \delta_{m}^{2}+\sum X_{i}^{2} \delta_{e i}^{2}
$$

Untuk memperoleh gambaran yang jelas dari hasil pemecahan masalah, perlu diidentifikasikan point - point dari pengolahan data yang dianggap signifikan. Hal ini dimaksudkan untuk memberikan argumen yang kuat terhadap hasil penelitian, sehingga penyusunan penelitian ini adalah penelitian yang punya landasan teori yang kuat.

Kesimpulan adalah hasil (output) dari keseluruhan penelitian. Dan untuk memperoleh kesimpulan yang valid perlu diselaraskan dengan tujuan dari penelitian yang telah ditetapkan semula.

Dalam proses pengumpulan data, data yang diolah untuk proses berikutnya adalah daftar tingkat bunga pertahun dalam hal ini periode tahun 2001 untuk dicari mean (rata-rata)nya. Dari data tingkat bunga tahun 2001 diperoleh mean sebesar 0,01386 atau 1,386 persen per bulan.

Untuk pengolahan data dilakukan perhitungan untuk mencari:

$\square$ Tingkat Return Saham (Rit)

$\square$ Expected Return Saham E(Ri)

$\square$ Varians dan Standar Deviasi ( $\delta$ )

$\square$ Koefisien Beta $(\beta \mathrm{\imath})$

$\square$ Koefisien alfa $(\alpha \mathrm{l})$

口Unsystematics Risk ( $\left.\delta \varepsilon^{2}{ }^{2}\right)$

a ERB dan Ci 


$\square$ Proporsi Sekuritas Xi (\%)
Tingkat Keuntungan dan Resiko
Portofolio E(Rp)

\section{HASIL DAN PEMBAHASAN}

\section{Tingkat Keuntungan Saham Individual}

Hasil perhitungan tingkat return saham pada tahun 2000 , tingkat keuntungan pasar berkisar antara - 0,01161(-1,161\%) sampai dengan $0,01644(1,644 \%)$, Sedangkan untuk tahun 2001, tingkat keuntungan rata - rata (return market) berkisar antara $-0,01539(1,539 \%)$ sampai dengan $0,00981(0,981 \%)$.

Selanjutnya, investor mempertimbangkan hasil yang diharapkan dari setiap saham dengan kemungkinannya (Probability) kemudian seluruh hasil dijumlahkan Dalam penelitian ini, nilai probabilitas untuk tahun 2000 adalah (1/12) dan untuk tahun 2001 adalah (1/8) Demikian pula untuk Expected Return Pasar dapat dihitung dengan cara yang sama, namun karena perubahan tingkat keuntungan tidak dinyatakan secara eksplisit maka tingkat keuntungan yang diharapkan tidak lain merupakan rata - rata dari tingkat keuntungan saham - saham individual.

Hasil Perhitungan dapat dilihat bahwa, pada tahun 2000 diperoleh tingkat keuntungan pasar (Return Market) sebesar - 2,776\%. Kondisi ini disebabkan karena banyaknya saham - saham perusahaan yang mengalami penurunan cukup tajam, dari 173 saham yang diteliti ternyata, terdapat 107 atau $61,85 \%$ perusahaan yang memiliki tingkat keuntungan dibawah rata - rata pasar Sedangkan saham - saham yang mengalami kerugian atau saham - saham yang memiliki nilai dibawah nol sebanyak $73,41 \%$. Saham yang memiliki tingkat return terbesar adalah Ever Shine Textile Ind. sebesar 24,91\%.

Pada tahun 2001 terdapat 52,02 \% yang mengalami kerugian, kondisi ini lebih baik jika dibandingkan dengan tahun 2000 . sedangkan tingkat keuntungan diatas rata rata pasar terdapat 108 dari 173 saham yang diteliti atau sebesar $62,42 \%$, diantara 2 saham yang memiliki tingkat keuntungan terbesar adalah Mas Murni Indonesia dan Ultra Jaya Milk masing - masing sebesar $39,58 \%$ dan 18,66 \%, sedangkan Ever Shine Textile Industries mengalami penurunan yang cukup tajam yakni sebesar $0,33 \%$.

Pada priode 2000 - 2001, saham Mas Murni Indonesia dan Ever Shin Textile Industries tetap unggul yakni sebesar 16,90 $\%$ dan $12,29 \%$. Saham - saham dari keseluruhan perusahaan berkisar antara $10,17 \%$ sampai dengan $16,90 \%$, sedangkan tingkat pengembalian pasar (Return) sebesar $-1,17 \%$, hal ini disebabkan karena banyaknya perusahaan yang mengalami kerugian yakni sebesar $66,47 \%$. Ini menggambarkan bahwa kondisi pasar modal Indonesia selama 2 priode, terutama pada tahun 2000 kurang menguntungkan. Kondisi stabilitas nasional yang buruk disertai memanasnya suhu perpolitikan memungkinkan menjadi factor pemicu lesunya pasar modal Indonesia 


\section{Resiko Individual}

Resiko yang dihitung dalam penelitian ini adalah standar predictor adalah beta, koefisien beta diolah dari hasil perhitungan varians dan standar deviasi deviasi, beta dan unsystematics risk. Namun dari ketiga resiko tersebut yang menjadi variable

Hasil penelitian dapat diperoleh resiko pasar $\left(\delta_{\mathrm{m}}\right)$ sebesar $0,93912(93,91 \%)$. Dari 173 saham yang diteliti terdapat 53 atau 30,64\% yang memiliki standar deviasi lebih besar dari 1 , sedangkan jumlah saham perusahaan yang lebih besar dari resiko pasar sebanyak 59 atau $34,01 \%$. Hubungan antara tingkat keuntungan dengan standar deviasi ternyata mempunyai hubungan yang positif, seperti yang ditunjukan pada saham Mas murni Indonesia dengan tingkat keuntungan yang diperoleh sebesar 12,29\% memiliki tingkat resiko sebesar $223,20 \%$ begitu pula dengan saham Ever shine dan Ultra jaya milk yang masing - masing memiliki tingkat resiko sebesar $300,39 \%$ dan $229,68 \%$. Sedangkan saham - saham yang memiliki tingkat resiko yang paling kecil adalah saham makindo sebesar 16,62 \% dengan tingkat Return yang positif yakni sebesar $27,3 \%$, selanjutnya diikuti oleh saham Sunsan textile dengan resiko $30,60 \%$, namun sayangnya saham ini memiliki tingkat resiko yang negatif yakni, sebesar $24,7 \%$. Dari saham - saham individual tersebut, dapat dinyatakan bahwa 2 saham yang memiliki tingkat keunggulan teratas adalah Saham Sarasa Nugraha dengan tingkat keuntungan dan resiko sebesar $5,59 \%$ dan $65,39 \%$

\section{Resiko sistematics (Beta).}

Koefisien beta disebut sebagai resiko pasar (market risk), karena tingkat fluktuasi yang terjadi disebabkan oleh factor - factor yang mempengaruh semua perusahaan yang beroperasi. Dari perhitungan didapatkan koefisien beta saham - saham individual berkisar antara $13,36 \%$ sampai dengan $254,53 \%$ dan terdapat $21,96 \%$ saham agresif, dan sisanya termasuk saham defensif. Saham agresif menunjukan tingginya unsur kepekaan terhadap perubahan pasar. Oleh karena itu pada kondisi bearish market, saham dengan koefisien beta yang rendah akan lebih aman dan lebih menguntungkan daripada saham saham yang memiliki angka koefesien beta yang tinggi.

Hasil penelitian menunjukan, bahwa saham - saham yang memiliki koefisien beta besar adalah polysindo dan evershine textile industries dengan tingkat kepekaan masing - masing sebesar 254,53 $\%$ dan 241, $41 \%$, sedangkan saham makindo $(\beta=13,36 \%)$ adalah saham dengan tingkat kepekaan yang paling kecil, sekaligus tetap berada pada tingkat keunggulan teratas. Meskipun ada beberapa saham dengan tingkat return positif memiliki koefisien beta yang kecil. Tetapi, secara keseluruhan saham - saham dengan tingkat return negatif umumnya memiliki koefisien yang kecil.

\section{Koefisien Alfa \\ Koefisien alfa menunjukan intercept dari persamaan regresi yang}


merupakan nilai pengharapan dari bagian tingkat keuntungan saham individual yang tidak dipengaruhi oleh perubahan pasar. Hasil penelitian menunjukkan bahwa nilai alfa berkisar antara $-10 \%$ sampai dengan 19 $\%$ dan terdapat $66,47 \%$ dari saham - saham yang memiliki koefisien alfa negatif, berarti jauh dari yang diharapkan, umumnya saham - saham yang memiliki koefisien negatif adalah karena tingkat keuntungan yang diperoleh juga negatif. Hal ini dikarenakan dalam perhitungan koefisien alfa terdapat tiga variable yang mempengaruhi yakni $E(R i), E(R m)$ dan koefisien $\tilde{T}$ karena nilai $E(R m)$ diperoleh negatif maka ketiga variable tersebut memiliki hubungan yang positif dengan nilai alfa. Sedangkan diantara 5 (lima) saham yang memiliki koefisien terbesar adalah; Mas Murni Indonesia, Evershine Textile Industries, Ultra jaya Milk, Parashida aneka dan sari husada yang masing - masing perolehannya adalah $19,00 \% ; 15,12 \% ; 12,47 \% ; 11,91 \%$ dan $11,91 \%$.

\section{Resiko Tidak Sistematics (Unsystematics Risk).}

Hasil perhitungan tampak bahwa saham makindo dan Sunsan Textile Manufacturing tetap unggul dengan tingkat resiko masing - masing sebesar $1,087 \%$ dan $3,68 \%$, dari tabel tersebut diperoleh resiko saham - saham yang memiliki nilai lebih besar dari satu terdapat 19 saham atau 10,98 $\%$ dari 173 saham yang diteliti

\section{Tingkat Bunga Bebas Resiko}

Dalam penelitian ini tingkat bunga bebas resiko ditentukan dari suku bunga Sertifikat Bank Indonesia (SBI) dengan nilai mean sebesar 0,166 atau 16,6 persen, kemudian hasil rata - rata tersebut dirubah menjadi data bulanan sehingga diperoleh nilai mean sebesar 0,01386 atau 1,386 persen.

\section{Pembentukan Portofolio dengan Metode Kriteria Sederhana}

Untuk mendapatkan kandidat saham - saham yang dimasukkan kedalam pembentukan portofolio, perlu ditentukan terlebih dahulu nilai Excess Return To Beta $(E R B)$, kemudian dihitung nilai C - nya, yang digunakan untuk menetapkan nilai Unique Cutt Of point.

Excess Return didefinisikan sebagai selisih return expektasi dengan return aktiva bebas resiko. Excess return to beta digunakan untuk mengukur kelebihan return relatif terhadap satu unit resiko yang tidak dapat di diversikasikan yang diukur oleh koefisien beta. Rasio ERB ini juga menunjukan hubungan antara dua factor penentu investasi, yaitu return dan resiko.

Portofolio yang optimal akan berisi dengan aktiva - aktiva yang mempunyai nilai rasio ERB yang tinggi. Aktiva - aktiva dengan ERB yang rendah tidak akan dimasukan kedalam portofolio. Dengan demikian diperlukan sebuah titik pembatas (Unique Cutt Of Point) yang akan menentukan batas nilai ERB berapa yang dikatakan tinggi. 
Hasil perhitungan yang diperlihatkan bahwa dari 173 saham setelah dilakukan perbandingan ternyata hanya terdapat 12 saham atau $6,94 \%$ saham yang dapat didiversifikasi pembentukan portofolio dengan baik. Dimana batas pemisah atau Unique Cut - Off Point adalah saham Unilever Indonesia Tbk, dengan nilai ERB sebesar $\quad 3,61 \%$. Dari tabel tampak bahwa, yang memiliki tingkat Excess Return terbesar adalah Makindo Tbk sebesar 10,03\%. Umumnya, Saham - saham yang dapat didiversifikasi dengan pembentukan portofolio adalah saham - saham dengan tingkat Return positif. Berikut ini disajikan daftar saham - saham yang masuk dalam pembentukan portofolio optimal.

Tabel 1

Saham - Saham Portofolio

\begin{tabular}{|l|l|r|r|r}
\hline NO. & $\begin{array}{c}\text { NAMA } \\
\text { PERUSAHAAN }\end{array}$ & E(Ri) & BETA & ERB \\
\hline 1 & Makindo Tbk & $2,73 \%$ & $13,36 \%$ & $10,0 \%$ \\
\hline 2 & Mas Murni Indonesia & $16,90 \%$ & $179,38 \%$ & $8,65 \%$ \\
\hline 3 & Sarasa Nugraha & $5,59 \%$ & $52,55 \%$ & $8,00 \%$ \\
\hline 4 & Takarta Int I Hotel & $5,93 \%$ & $77,81 \%$ & $5,83 \%$ \\
\hline 5 & Sari Husada Tbk & $9,91 \%$ & $147,66 \%$ & $5,77 \%$ \\
\hline 6 & Ultra Jaya Milk & $10,31 \%$ & $184,59 \%$ & $4,83 \%$ \\
\hline 7 & Prasidha Aneka & $9,82 \%$ & $179,22 \%$ & $4,70 \%$ \\
\hline 8 & Ever Shine Textile Ind & $12,29 \%$ & $241,41 \%$ & $4,52 \%$ \\
\hline 9 & Tirta Mahakam Plwd & $7,26 \%$ & $147,47 \%$ & $3,98 \%$ \\
\hline 10 & Asahimas flat Glass & $3,23 \%$ & $50,84 \%$ & $3,64 \%$ \\
\hline 11 & Semen Gresik & $5,53 \%$ & $114,37 \%$ & $3,62 \%$ \\
\hline 12 & Unilever Ind Tbk & $2,91 \%$ & $42,11 \%$ & $3,61 \%$ \\
\hline
\end{tabular}

\section{Proporsi Saham}

Dari hasil perhitunganl diperoleh tingkat proporsi sekuritas terbesar adalah dimiliki oleh saham Makindo sebesar 72,08 \%, kemudian Sarasa Nugraha sebesar 12,66 $\%$. Sedangkan proporsi yang paling kecil dalam portofolio optimal adalah saham Semen Gresik sebesar 0,18 \%

\section{KESIMPULAN}

Dengan membandingkar antara hasil pengolahan data dan penetapan tujuan semula maka, dapat diambil beberapa kesimpulan sebagai berikut

1. Dari 173 saham yang diteliti ternyata hanya diperoleh 12 atau $6,94 \%$ saham saham yang masuk seleksi pembentukan portofolio, diantara daftar saham - saham tersebut adalah sebagai berikut ;

Tabel 2

Persentase Saham Portofolio

\begin{tabular}{|c|c|c|c|c|}
\hline No. & $\begin{array}{c}\text { NAMA } \\
\text { PERUSAHAAN }\end{array}$ & $\mathbf{E}(\mathbf{R i})$ & BETA $(\beta)$ & $\mathbf{X i}(\%)$ \\
\hline 1 & Makindo Tbk & $2,73 \%$ & $13,36 \%$ & $72,08 \%$ \\
\hline 2 & Mas Murni Indonesia & $16,90 \%$ & $179,38 \%$ & $4,24 \%$ \\
\hline 3 & Sarasa Nugraha & $5,59 \%$ & $52,55 \%$ & $12,66 \%$ \\
\hline 4 & Jakarta Int I Hotel & $5,93 \%$ & $77,81 \%$ & $4,45 \%$ \\
\hline 5 & Sari Husada Tbk & $9,91 \%$ & $147,66 \%$ & $2,28 \%$ \\
\hline 6 & Ultra Jaya Milk & $10,31 \%$ & $184,59 \%$ & $1,08 \%$ \\
\hline 7 & Prasidha Aneka & $9,82 \%$ & $179,22 \%$ & $1,00 \%$ \\
\hline 8 & Ever Shine Textile & $12,29 \%$ & $241,41 \%$ & $0,63 \%$ \\
\hline 9 & Tirta Mahakam Plwd & $7,26 \%$ & $147,47 \%$ & $0,50 \%$ \\
\hline 10 & Asahimas flat Glass & $3,23 \%$ & $50,84 \%$ & $0,44 \%$ \\
\hline 11 & Semen Gresik & $5,53 \%$ & $114,37 \%$ & $0,18 \%$ \\
\hline 12 & Unilever Indonesia & $2,91 \%$ & $42,11 \%$ & $0,45 \%$ \\
\hline
\end{tabular}

\section{Dimana E(Ri =Tingkat Keuntungan Saham $\beta \quad=$ Tingkat kepekaan Pasar (Resiko) $X i=$ Prosentase Proporsi saham.}

2.Tingkat keuntungan yang diharapkan (expected Return) dari masing - masing saham (12 saham portofolio) diperoleh sebesar $(0,0756)$ atau 7,56 persen.

3. Tingkat resiko (standar deviasi) portofolio dari masing - masing saham (12 saham portofolio) diperoleh sebesar $(0,4226)$ 
atau 42,26 persen, berarti lebih kecil dari 1 , kondisi ini menunjukan tingkat kepekaan resiko saham - saham portofolio berada pada posisi yang tidak terlalu membahayakan. Sekaligus membuktikan bahwa dengan pembentukan portofolio dapat mengurangi resiko secara efektif. $(42,24 \%<292,41 \%)$ atau jika menggunakan barometer koefisien beta $(3,115 \%<119,23 \%)$

\section{DAFTAR PUSTAKA}

Husnan, Suad, DR, MBA., 1996, Dasar Dasar Teori Portofolio dan Analisa Sekuritas, UPP AMP YKPN, Yogyakarta.

Fabozzi, J. Frank.,Modigliani, Franco., Ferri. G, Michael., 1994, Foundations of Financial Markets and Institutions, Simon \& Schuster (Asia) Pte. Ltd., Prentice-Hall.

Sharpe.F, William., Alexander.J,Gordon., Bailey.V, Jeffery., 1995, Investasi, Edisi I dan II, PT.Prenhallindo, Jakarta.
Hadi, Syamsul., 1998, Skripsi Pengaruh

Nilai Saham Terhadap Pengambilan Keputusan Investor Untuk Melakukan Transaksi Saham Perbankan Pada PT. Bursa Efek Surabaya, FE - Universtas Muhammadiyah Malang.

Suryadi,Indra,1995, Skripsi Analisa Pemilihan saham untuk portofolio optimal dgn Metode Kriteria sederhana(Studi Kasus di PT.Bursa Efek Surabaya,FTI - ITS.

Yuliati.H, Sri, MBA., Prasetyo, Handoyo, SE., Tjiptono, Fandy, SE., 1996, Manajemen Portofolio dan Analisa Investasi, Penerbit ANDI, Yogya. Sudjana, Prof, DR., 1992, Metoda Statistika, Penerbit Tarsito, Bandung. 